\title{
LOS ORÍGENES DE UN HÉROE: EDIPO EN COLONO
}

\author{
MíRIAM CARRILLO RODRÍGUEZ \\ Universidad de Málaga \\ miriamcr@uma.es \\ ORCID: 0000-0002-7819-6360
}

\section{RESUMEN}

En el presente trabajo haré un análisis de la evolución de Edipo de mortal a héroe en Edipo en Colono. Para ello tomaré como base la descripción que hace el poeta de las limitaciones mortales del personaje (vejez, ceguera, debilidad, míasma...) y la forma en que Edipo se sobrepone a ellas en el momento de su muerte y heroización. Luego pondré en contexto la obra en el marco de las tradiciones antiguas sobre la muerte y el culto de Edipo. Esto mostrará cómo Sófocles pudo haber puesto en escena elementos del paisaje ático y el culto a Edipo que podrían haber sido conocidos por los espectadores.

PALABRAS CLAVE: Edipo en Colono, Sófocles, héroe, culto heroico.

\section{THE ORIGINS OF A HERO: OEDIPUS AT COLONUS}

\section{ABSTRACT}

In this paper, I will analyse the transition of Oedipus from mortal to hero in Oedipus at Colonus. This analysis will be based on the description the poet gives about the mortal character's limitations, such as old age, blindness, weakness and míasma, and the way Oedipus overcomes them when his death and heroization are near. Then, I will contextualize the play within the ancient traditions about Oedipus' death and cult. This will illustrate how Sophocles could have staged elements of the Attic landscape and Oedipus' cult which may have been known to the audience.

KEYWORDS: Oedipus at Colonus, Sophocles, hero, hero cult.

El concepto griego de «héroe» es diferente del que tenemos actualmente. En los poemas homéricos se denomina «héroes» a aquellos guerreros con el potencial de llevar a cabo grandes hazañas; el término no tiene ningún tipo de connotación religiosa y no implica que los personajes a los que el poeta llama así sean premiados con una inmortalidad post mortem, ni que sean objeto de culto religioso tras su muerte. Un uso más tardío del término, en cambio, indica que el héroe es un individuo que, una vez muerto, posee cierta influencia sobre el mundo de los vivos y exige que se le rindan honores, lo que conocemos como «culto heroico». ${ }^{1}$ En esta última categoría se cuentan numerosas figuras del mito que recibieron culto como Pélope, Aquiles, Áyax o Edipo (en el que me centraré en las siguientes páginas), y tampoco faltan ejemplos femeninos como Helena, Ifigenia o

\footnotetext{
${ }^{1}$ Para un estudio sobre el estatus particular del héroe, véase González González (2018: 16-19).
} 
Casandra. ${ }^{2}$ Sin embargo, también fue común el rendir culto heroico a figuras

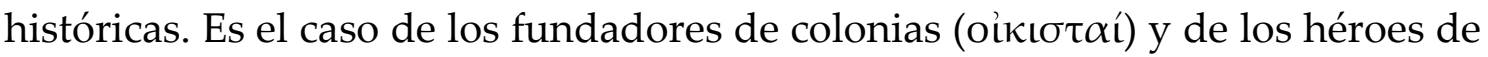
guerra, especialmente a partir de época clásica. En época helenística, este proceso fue especialmente notable $\mathrm{y}$, en efecto, se hizo frecuente la heroización de gobernantes y otros individuos de alto estatus.

Los héroes gozan de un estatus intermedio entre los mortales y los dioses. Mueren, como corresponde a todo ser humano, y es precisamente a partir de su muerte cuando surge un culto en torno a su cuerpo o a su tumba, que se creían una fuente de poder y protección. Edipo en Colono es una obra que muestra muy claramente estas características: Edipo, que acaba de ser exiliado de Tebas, llega con ayuda de Antígona al bosque sagrado de las Euménides, en Colono, donde un oráculo había predicho que moriría. Allí, se acoge como suplicante para no ser expulsado de la ciudad y, al final, es recibido por Teseo, que le permite quedarse. Según los oráculos, el sitio donde Edipo muriera recibiría su protección y los tebanos buscarán a Edipo para tratar de llevárselo de vuelta. Y, en efecto, eso es lo que acaba pasando: Creonte llega a Colono de parte de Eteocles con la intención de obligar a Edipo a volver a Tebas; a su vez, Polinices trata de convencer a su padre de unirse a él, que deseaba destronar a su hermano y ser rey. Edipo, con la ayuda de Teseo, rechaza las pretensiones de ambos. La obra acaba con la muerte de Edipo y su heroización en Colono, pero la transición de simple mortal a héroe se hace patente a lo largo de toda la obra.

\section{EL CUERPO DEL HÉROE EN EDIPO EN COLONO: CONTAMINACIÓN Y MORTALIDAD}

Es significativa la evolución de Edipo a héroe, que se hace más y más notable cuanto más se acerca su muerte. El cambio en Edipo se manifiesta en la forma en que su cuerpo supera sus limitaciones humanas (edad, ceguera, debilidad...) y en cómo es percibido por los demás. Edipo es un anciano ciego y débil, que necesita a su hija para sobrevivir, y que carga sobre su cuerpo la míasma por el asesinato de Layo y su matrimonio con Yocasta. El tebano es un miarós, una persona contaminada y estigmatizada por su crimen, cuestión especialmente delicada debido al lugar en el que transcurre la obra: el bosque de las Euménides, un lugar sagrado y, por ende, especialmente vulnerable ante la contaminación. ${ }^{3}$

Tanto la míasma como la súplica juegan un papel fundamental en la obra, debido a sus implicaciones religiosas: cuando Edipo revela quién es al coro (formado por habitantes de Colono), ellos se horrorizan y le instan a marcharse, temiendo que su presencia les ocasione algún mal (220 y ss.). Los habitantes de Colono temen las consecuencias de aceptar a un miarós en la ciudad y dejarlo

\footnotetext{
${ }^{2}$ Sobre el tema de las heroínas griegas son fundamentales los estudios de Larson (1995) y Lyons (1997).

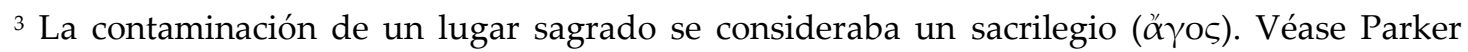
(1983: 8).
} 
profanar territorio sagrado, pero tampoco pueden obligar al suplicante a marcharse, pues el expulsar, matar o dejar morir a un suplicante se consideraba un sacrilegio.

La míasma también influye en gran medida en la forma en que el resto de los personajes percibe el cuerpo de Edipo y en cómo interactúa el tebano con ellos: en el transcurso de toda la obra, el coro constantemente expresa su miedo a que un hombre contaminado esté entre ellos, en un lugar sagrado. Creonte incluso afirma que pensaba que la ciudad no recibiría a «un hombre parricida e

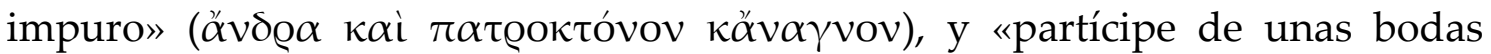
impías» ( $\alpha$ vóotol, 944 y ss.). Es esta impureza la razón de que el coro pida a Edipo que lleve a cabo un rito de «purificación» ( $\kappa \alpha \theta \alpha \varrho \mu o ́ \varsigma)$ ante las Euménides (466 y ss.), gesto que cobra un gran valor simbólico, al ser estas diosas las vengadoras de los crímenes familiares.

La míasma es también la razón por la cual Edipo no puede ser enterrado en Tebas en caso de volver. Cuando Ismene entra en escena, informa a su padre de las disputas de Eteocles y Polinices por el poder de Tebas y de la intención de Creonte de instalar a Edipo a las afueras de la ciudad, haciendo énfasis en que no será enterrado en tierra tebana debido al asesinato de Layo (396-407). Más tarde, Creonte captura a Antígona e Ismene a fin de obligar a Edipo a volver a Tebas, pero ambas son devueltas por Teseo a su padre. El tebano, agradecido, se aproxima para tomar la mano del rey ateniense y besar su rostro, pero se detiene en el último momento, dando a entender que nadie, salvo sus hijas, debe tocar su cuerpo (1130 y ss.).

Tanto la míasma como las limitaciones mortales de Edipo contrastan en gran medida con el potencial heroico que demuestra el personaje a lo largo de la obra y con los beneficios que Edipo brindará al Ática una vez muerto. Edipo es un anciano de gran debilidad y frecuentemente se hace alusión al lamentable aspecto de sus ropas y su cuerpo (109-110, 285-286, 495-503, 555-556 y 1256-1263). Por otra parte, una de las mayores limitaciones de Edipo, y sin duda una de las más representativas, es su ceguera. Como mortal, Edipo no puede ver y necesita constantemente de un guía para poder moverse a su alrededor. Sin embargo, como héroe en potencia, el personaje demuestra una clase de visión que va más allá de lo meramente físico. ${ }^{4}$ Aunque Edipo es ciego, al igual que Tiresias en Edipo Rey, es capaz de «ver» lo que está por llegar: el tebano profetiza la muerte de Eteocles y Polinices el uno a manos del otro (421-427, 789-790 y 1383-1396) y las desgracias que sufrirán Creonte y su familia (864-870), profecías, además, de un carácter sobrenatural, en tanto que Edipo las profiere en forma de maldiciones que surtirán efecto una vez de que él ya haya muerto y sea un héroe. Esta clase de «visión» de Edipo es especialmente notable precisamente momentos antes de su muerte, pues, cuando el tebano ha de buscar el lugar donde reposará su

\footnotetext{
${ }^{4}$ La ceguera es una característica muy repetida en personajes del mito como adivinos y poetas, véase Bettini y Guidorizzi (2008: 111-119).
} 
cuerpo, lo hace, para maravilla de todos, sin necesidad de un guía y guiando él a los demás, como si pudiera ver (1587 y ss.).

Estas características, físicas (vejez, ceguera, debilidad) y no físicas (míasma) dotan al cuerpo de Edipo de una apariencia indeseable que contrasta en gran medida con los beneficios que, según los oráculos, su cuerpo otorgará al lugar donde sea enterrado (87-95). Esta dualidad queda especialmente patente en las palabras que Edipo dirige a Teseo cuando se presenta ante él: «He venido para ofrecerte el don de mi infortunado cuerpo. No es apreciado para la vista, pero los beneficios que de él obtendrás son mejores que un bello aspecto». ${ }^{5}$

Los beneficios que traerá Edipo son profetizados por el oráculo de Apolo: algún día los tebanos invadirán el Ática y Edipo dará protección a los atenienses (409 y ss., 619 y ss., 1518 y ss.). Esta guerra entre Atenas y Tebas podría ser muy evocadora para los espectadores de Edipo en Colono, pues posiblemente Sófocles aludiera a un conflicto entre ambas ciudades en el marco de los últimos años de la guerra del Peloponeso, idea apoyada por el hecho de que los espartanos hicieron una incursión en Decelea con ayuda de los tebanos poco tiempo antes de la composición de Edipo en Colono. ${ }^{6}$

Otro elemento que refleja el tránsito de Edipo a héroe son los singulares sucesos que rodean su muerte. Cuando su paso al otro mundo se acerca, Edipo insiste en que el único al que se permite saber la localización de la tumba es al rey ateniense, y que este deberá mantenerlo en secreto y solo decírselo a uno de sus descendientes (1520 y ss.). El paso de Edipo a la otra vida se parece más a una katábasis que a una muerte y funeral propiamente dichos, de acuerdo con la descripción del lugar al que se aproximó Edipo para morir:

Una vez que llegó al abrupto camino sólidamente arraigado desde la tierra por broncíneos cimientos, se detuvo en uno de los senderos que se bifurcan, cerca de la cóncava hondonada de la roca, donde reposan los pactos de lealtad eterna entre Teseo y Pirítoo. A partir de aquí, colocándose en el medio, entre la roca Toricia y el peral silvestre hueco y la tumba de piedra, se sentó. ${ }^{7}$

Llegado el momento, truena Zeus Infernal y una divinidad desconocida llama a Edipo desde el otro lado. Entonces, según el mensajero, el tebano desaparece, dejando solo a Teseo (1648-1652). Esto es significativo porque, pese a que durante toda la obra se ha hecho énfasis en que Edipo debía recibir «sepultura» en Colono, y se ha llamado a aquel lugar la «tumba sagrada» de

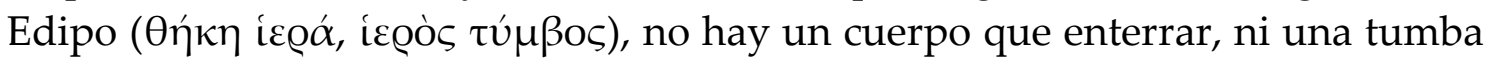
física. Según Antígona, Edipo fue tragado por el otro mundo (1678-1683), e Ismene incluso dice que su padre murió $\alpha$ $\tau \alpha \varphi \circ \varsigma$, «sin enterrar» (1732). Esto dota de un cariz misterioso y sobrenatural a los hechos, si bien contrasta en gran

\footnotetext{
${ }^{5}$ S. OC. 576-578. Traducción de Alamillo (1981).

${ }^{6}$ Lardinois (1992: 323-324).

7 S. OC. $1590-1597$.
} 
medida con los cultos heroicos griegos corrientes, que suelen tener como punto de partida la recuperación de los restos de un héroe, o una tumba conocida.

\section{LA TRADICIÓN DE LA MUERTE Y CULTO HEROICO DE EDIPO}

Existen varias tradiciones literarias que sitúan la muerte de Edipo y la suerte de sus restos o su tumba en diversas ciudades, en algunos casos acompañadas de un culto en torno a su figura. Estas tradiciones se pueden localizar principalmente en dos regiones: en Beocia y en el Ática.

\subsection{Tradiciones beocias: Tebas, Ceos y Eteono}

La tradición más antigua, la épica, sitúa los funerales y la tumba de Edipo en Tebas, pero no menciona ninguna clase de culto (Hom. Il. 23, 677-680). Esta tradición todavía perdura en la tragedia griega del s. V a.C., pues Esquilo y el mismo Sófocles mencionan una tumba de Edipo en Tebas (A. Th. 914 y 1004; S. Ant. 899-902). ${ }^{8}$ Esto contrasta en gran medida con Edipo en Colono, que sitúa la tumba fuera de Tebas, debido a que incluye el tópos del destierro de Edipo y la mancha por el asesinato de su padre, que no permite que sea enterrado en la ciudad.

Otra tradición sitúa la tumba de Edipo no en Tebas, sino en dos ciudades cercanas a ella, Ceos y Eteono. Esta tradición podría tener orígenes tebanos: la noticia está en la Tebaida, obra de un autor desconocido llamado Aricelo, si bien este nombre parece ser de procedencia tebana. ${ }^{9}$ La obra hoy está perdida, pero conservamos un fragmento gracias a un escolio:

Los hay que dicen que la tumba de Edipo está en el templo de Deméter en Eteono, trasladada allí desde un pueblo desconocido de Ceos, como dice Lisímaco el de Alejandro que cuenta Aricelo en su decimotercer [¿en su tercer?] libro de la Tebaida, pues dice así: "tras morir Edipo, y pensando sus familiares si enterrarlo en Tebas, los tebanos los previnieron, en la idea de que él era impío por las desgracias que le habían sucedido. Decidieron entonces que lo enterrarían en un lugar de Beocia llamado Ceos. Pero como les ocurrieron ciertas desgracias a los que vivían en el territorio, pensaron que la causa era la tumba de Edipo y ordenaron a sus familiares que se lo llevaran del territorio. Ellos, desconcertados por lo ocurrido, tomaron el cadáver y lo llevaron a Eteono. Queriendo darle sepultura en secreto, lo enterraron de noche en el templo de Deméter, sin darse cuenta de dónde estaban. Cuando se dieron cuenta, los habitantes de Eteono enviaron un emisario al dios para preguntar qué debían hacer. Entonces el dios respondió que no expulsaran al suplicante de la diosa, por lo que lo dejaron enterrado

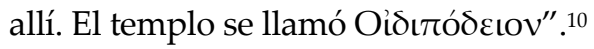

Aunque esta historia aún no incorpora el exilio de Edipo, posee diversos elementos en común con la de Sófocles. En primer lugar, está la prohibición de

\footnotetext{
8 Edmunds (1981: 225).

${ }^{9}$ Lardinois (1992: 326).

10 Schol. S. OC. 91. Traducción de la autora.
} 
enterrar a Edipo en Tebas por la mancha del asesinato de Layo, lo cual queda patente en el hecho de que se le considera «impío» ( $\dot{\alpha} \sigma \varepsilon \beta$ oṽ $\varsigma$ y en el temor de los habitantes de Tebas y Ceos a las desgracias que podría acarrear el enterrar a un miarós en su tierra. Otros puntos en común son la implicación del oráculo en el enterramiento de Edipo y la repetición del motivo de la súplica. No queda tan claro, en cambio, que el culto heroico a Edipo fuera también orden del oráculo, si bien el resultado es el mismo, como demuestra el templo en su honor. Finalmente, es también significativo el hecho de que la tumba de Edipo se sitúa en el recinto sagrado de una divinidad, en este caso no las Euménides, sino la diosa Deméter.

\subsection{Tradiciones áticas: Colono y el Areópago}

El otro foco de tradición del culto a Edipo es el Ática. Sófocles no es el primero en situar la muerte de Edipo y su culto en Colono, sino que posiblemente sigue una tradición preexistente, presente también en Eurípides (Ph. 1705-1707). ${ }^{11}$

El historiador Androción, del s. IV a.C., también sitúa la tumba de Edipo en Colono. Este es el testimonio más cercano (cronológica y temáticamente) al de Sófocles, pues, según la versión de Androción, Edipo es desterrado, se acoge como suplicante en un templo de Colono y recibe la ayuda de Teseo ante la intervención de Creonte. La principal diferencia frente a Edipo en Colono es que las divinidades a cuyo santuario se acoge Edipo no son las Euménides, sino Deméter, Atenea y Zeus, y que Edipo pide que su tumba sea un secreto por miedo a que sea ultrajada:

Edipo, desterrado por Creonte, marchó hacia el Ática y se estableció en Colono, llamado Hipio. Se hizo suplicante en el santuario de los dioses Deméter, Atenea protectora de la ciudad y Zeus. Queriendo llevárselo Creonte, Edipo consiguió que Teseo desconfiara de este, y cuando estaba a punto de morir de viejo, pidió a Teseo que no mostrara su tumba a ningún tebano, no fuera que desearan llevárselo y la ultrajaran. La historia está en Androción. ${ }^{12}$

En este caso, se hace referencia a una tumba de Edipo y, aunque no se menciona explícitamente un culto al tebano, el verbo utilizado para referirse a su establecimiento en la ciudad ( $\omega \kappa \eta \sigma \varepsilon v)$ tiene un matiz cultual que puede apuntar en dicho sentido. ${ }^{13}$

Según Pausanias, existía un templo compartido por Edipo y Adrastro en Colono, de acuerdo con una tradición que situaba a Edipo allí:

Se muestra también un lugar llamado Colono Hipio, el primer lugar del Ática al que dicen que Edipo llegó - esto es diferente de lo que dice la poesía de Homero, pero es una

\footnotetext{
${ }^{11}$ Se ha discutido que dichos versos pudieran ser una interpolación, si bien se ha defendido su autenticidad. Véase Lardinois (1992: 323 y n. 35).

12 Schol. Hom. Od. $\Lambda$ 271. Traducción de la autora.

${ }^{13}$ Edmunds (1981: 223 y n. 8).
} 
tradición - y un altar de Posidón Hipio y de Atenea Hipia, y un heróon de Pirítoo y Teseo, y otro de Edipo y Adrasto. El bosque sagrado de Posidón y el templo los incendió en un ataque Antígono, el que también devastó la tierra de los atenienses en otras ocasiones con su ejército. ${ }^{14}$

Resultan significativas las alusiones a Atenea y Posidón, especialmente al recinto sagrado y templo del último, mencionados en Edipo en Colono, así como al heróon de Teseo y Pirítoo, el cual puede ponerse en relación con el lugar donde, según Sófocles, «residían los pactos» de dichos héroes, cerca de donde Edipo murió (1593-1594).

Colono, sin embargo, no sería el único lugar del Ática conectado a la figura de Edipo. Según el mismo Pausanias (1, 28, 6-7), en el Areópago, situada en un recinto consagrado a las Euménides, existía una tumba de Edipo; pese a que sus funerales se habían celebrado en Tebas, sus huesos habían sido traídos desde allí. Valerio Máximo, por su parte, hace alusión a un altar en su honor en el Areópago, así como una posible tumba (5, 3, 3 ext.).

Como puede comprobarse, son numerosos los puntos en común de las diferentes tradiciones sobre la muerte y culto de Edipo con la obra de Sófocles. Un análisis de Edipo en Colono y estos testimonios muestra que Sófocles pudo utilizar varias tradiciones para ofrecer la suya propia.

\section{Conclusiones: Edipo en Colono y las tradiciones del culto a Edipo}

La mayoría de los testimonios acerca del culto a Edipo son posteriores a Sófocles, algo que hace difícil separar qué es tradición y qué innovación. Sin embargo, es bastante plausible que Sófocles se inspirara en tradiciones que sitúan el enterramiento y culto a Edipo en Eteono, Colono y el Areópago y las fusionara en su obra, tomando elementos de cada una que podrían haber sido conocidos por los espectadores.

Edipo en Colono incluye el tópico del exilio de Edipo y la prohibición de enterrarlo en la ciudad por el asesinato de Layo. El comentario de Ismene de que si Edipo volviera a Tebas no sería enterrado en la ciudad, sino en los alrededores, podría ser una sutil referencia a la tradición de Eteono, probablemente más antigua que la obra de Sófocles. ${ }^{15}$

Sófocles sitúa la muerte y culto de Edipo en Colono siguiendo, probablemente, una tradición preexistente, como demuestra el hecho de que Eurípides así lo hiciera en sus Fenicias, y que Pausanias haga referencia a un templo de Edipo y Adrastro en Colono. De ser esta tradición lo suficientemente antigua, Sófocles pudo trasladar la tumba de Edipo y el santuario de las Euménides del Areópago a Colono, fusionando dos cultos en uno solo. De no ser

\footnotetext{
14 Paus. 1, 30, 4. Traducción de Herrero Ingelmo (1994).

${ }^{15}$ Lardinois (1992: 326) y Kelly (2009: 42-43).
} 
lo suficientemente antigua, la obra pudo haber trasladado el culto del centro de la ciudad a Colono, o haber creado un culto totalmente nuevo. ${ }^{16}$

En la obra de Sófocles, la localización de la tumba de Edipo es un secreto guardado solo por unos pocos privilegiados. El que el lugar de la tumba de Edipo sea secreto es un tópos que pudo estar ya presente en la tradición, con la diferencia de que, mientras que el tebano originalmente pide que el lugar de su tumba sea oculto para que no sea ultrajada, en Edipo en Colono Sófocles reinterpreta esta idea y solo Teseo y sus descendientes conocen la localización de la tumba, pero no por miedo a que sea ultrajada, sino como un privilegio en relación con el culto al héroe.

El hecho de que Sófocles haga a las Euménides dueñas del recinto sagrado y no a Deméter, que era la diosa original del culto en Eteono, o a Deméter, Atenea y Zeus, del culto en Colono, encajaría mejor en el mito por su cualidad de divinidades vengadoras de los crímenes familiares, así como por su carácter dual, benéfico y maléfico. ${ }^{17}$ No obstante, aún se encuentran ecos de estas otras tradiciones en la obra de Sófocles: según el mensajero, el lugar al que se dirige Edipo para morir está cerca de una colina consagrada a Deméter (1600-1601), y tanto la Diosa Madre como las Erinias son divinidades femeninas, ctónicas y genealógicamente anteriores a Zeus, pero reintroducidas en el nuevo orden olímpico en las figuras de Deméter y las Euménides. Las otras divinidades, Atenea y Zeus, además de Posidón, están muy presentes en la acción de Edipo en Colono: Posidón y Atenea juegan un importante rol en la identidad y paisaje de Atenas. ${ }^{18}$ Zeus, por su parte, es la divinidad invocada por los personajes en momentos de gran tensión emocional, además de quien marca el momento en que Edipo ha de pasar al otro mundo, por medio de un rayo (1456 y ss., y 1606). ${ }^{19}$

De esta manera, Edipo en Colono combina diversos elementos del paisaje y panorama religioso ateniense, así como de las tradiciones tebanas y áticas sobre Edipo, y juega con lo que los espectadores ya conocían sobre la muerte y el culto al héroe.

\footnotetext{
${ }^{16}$ Kelly (2009: 43).

${ }^{17}$ Tanto las Euménides/Erinias como Edipo tienen un carácter dual, benéfico y maléfico; véase Edmunds (1981: 228-229). Sobre la función de estos personajes en la tradición épica y trágica previa a Edipo en Colono, véase Brillante (2014).

${ }^{18}$ Estas divinidades son clave en la descripción del paisaje de Edipo en Colono. Los tres, Atenea, Zeus y Posidón, están presentes en el elogio del coro a la ciudad de Colono (668 y ss.). Cerca del bosque sagrado de las Euménides se hallaba el recinto sagrado de Posidón (54 y ss.), donde Teseo menciona haber acudido a ofrecer sacrificios ( 887 y ss., 1491 y ss.), y donde Polinices se acoge como suplicante para poder hablar con Edipo (1156 y ss.). El coro menciona a Atenea y Posidón al hablar sobre el poderío de la caballería ateniense, y tanto la diosa como Zeus son invocados para pedir ayuda cuando Creonte trata de llevarse a las hijas de Edipo (1067 y ss.).

${ }^{19}$ Sobre la relación de Edipo con Posidón, Atenea y Zeus en Edipo en Colono, véase Kelly (2009: 68-71).
} 


\section{BIBILIOGRAFÍA}

BETTINI, M. y GUIDORIZZI, G. (2008), El mito de Edipo: imágenes y relatos de Grecia a nuestros días, Madrid, Akal.

BRILLANTE, C. (2014), «Edipo e le Erinni: dall' Odissea all' Edipo Re», QUCC, 108/1, 11-45.

EDMUNDS, L. (1981), «The Cults and the Legend of Oedipus», HSCP, 85, 221-238.

GONZÁLEZ GONZÁLEZ, M. (2018), Creencias y rituales funerarios. El más allá en la Grecia Antigua, Madrid, Síntesis.

Herrero Ingelmo, M. C. (1994), Pausanias. Descripción de Grecia, vol. 1, Madrid, Gredos.

Kelly, A. (2009), Sophocles: Oedipus at Colonus, Londres, Duckworth.

LARDINOIS, A. (1992), «Greek Myths for Athenian Rituals: Religion and Politics in Aeschylus' Eumenides and Sophocles' Oedipus Coloneus», GRBS, 33, 313-327.

LARSON, J. L. (1995), Greek Heroine Cults, Wisconsin, University of Wisconsin.

LASSO DE la VeGa, J. y Alamillo, A. (1981), Sófocles. Tragedias, Madrid, Gredos.

LYONS, D. (1997), Gender and Immortality: Heroines in Ancient Greek Myth and Cult, Princeton, Princeton University.

PARKer, R. (1983), Miasma: Pollution and Purification in Early Greek Religion, Oxford y Nueva York, Clarendon. 
